\title{
UJI TOKSISITAS AKUT DARI KOMBINASI EKSTRAK HERBA MENIRAN (Phyllanthus niruri auct. Non L.), DAUN TEMPUYUNG (Sonchus arvensis L.) DAN BIJI JINTEN HITAM (Nigella sativa L.)
}

\section{ACUTE TOXICITY TESTING OF EXTRACTS COMBINATION OF MENIRAN HERBS (Phyllanthus niruri auct. Non L.), TEMPUYUNG LEAVES (Sonchus arvensis L.) AND BLACK CUMIN SEEDS (Nigella sativa L.)}

\author{
Muhtadi ${ }^{\star}$, Andi Suhendi, Nurcahyanti W., dan EM. Sutrisna \\ Fakultas Farmasi, Universitas Muhammadiyah Surakarta \\ pmuhtadi@gmail.com
}

\begin{abstract}
ABSTRAK
Telah dilakukan uji toksisitas akut pada tikus jantan dan betina dari kombinasi ekstrak herba meniran (Phyllanthus niruri auct. Non L.), daun tempuyung (Sonchus arvensis L.) dan biji jinten hitam (Coleus ambonicus Lour). Pengujian dilakukan dengan cara pemberian sediaan uji yang berupa kombinasi ekstrak dengan formula 1,5:3:1,5 dosis tunggal dengan peringkat dosis sebagai berikut: dosis I; $100 \mathrm{mg} / \mathrm{kgbb}$, dosis II; $300 \mathrm{mg} / \mathrm{kgbb}$, dosis III; $900 \mathrm{mg} / \mathrm{kgbb}$, dosis IV; $2.700 \mathrm{mg} / \mathrm{kgbb}$ dan dosis $\mathrm{V} ; 8.100 \mathrm{mg} / \mathrm{kg} \mathrm{bb}$. Kemudian dilakukan pengamatan gejala-gejala klinis yang timbul, perubahan berat badan per minggu dan histopatologi organ-organ vital yaitu: hati, ginjal, lambung, usus, limfa, jantung dan paru-paru. Pengamatan dilakukan selama 14 hari. Dari hasil penelitian dapat disimpulkan bahwa dosis tertinggi hingga $8100 \mathrm{mg} / \mathrm{kgbb}$ dari kombinasi ekstrak tersebut hampir tidak toksik terhadap tikus putih betina dan jantan galur SD.
\end{abstract}

Kata kunci : uji toksisitas akut; kombinasi ekstrak; tikus jantan dan betina galur SD.

\section{ABSTRACT}

Acute toxicity testing were conducted in male and female rats of extracts combination of meniran herbs (Phyllanthus niruri auct. Non L.), tempuyung leaves (Sonchus arvensis L.) and black cumin seeds (Nigella sativa L.). Examination was done by preparation of the extract combinations with the formula 1.5: 3: 1.5 single dose to rank the following doses l-V: $(100 \mathrm{mg} / \mathrm{kg} \mathrm{bw}, 300 \mathrm{mg} /$ $\mathrm{kg} \mathrm{bw}, 900 \mathrm{mg} / \mathrm{kg} \mathrm{bw}, 2700 \mathrm{mg} / \mathrm{kg}$ bw and $8100 \mathrm{mg} / \mathrm{kg} \mathrm{bw})$. Then, the observed clinical symptoms arised, changing body weight per week and histopathology of vital organs were: liver, kidney, stomach, intestine, spleen, heart and lungs. Observations were made for 14 days. The research can be concluded that the highest dose of up to $8100 \mathrm{mg} / \mathrm{kg}$ of the extract combination hardly toxic to male and female white mice strain $S D$.

Key word : acute toxicity testing, extracts combination, male and female white mice strain SD

\section{PENDAHULUAN}

Indonesia merupakan negara terkaya di dunia dalam kekayaan hayati, dengan luas yang 'hanya' $1,3 \%$ dari luas total daratan dunia, Indonesia dianugerahi dengan kekayaan alam yang beraneka ragam, baik tumbuhan, ikan, ampibi dan hewan-hewan lainnya. Potensi kekayaan tumbuhan dapat dimanfaatkan untuk menunjang berbagai macam kebutuhan hidup manusia, terutama dalam bidang obat-obatan dari tumbuhan. Pada kenyataannya ramuan dari tumbuhan tersebut masih banyak dimanfaatkan serta memberi andil pada pemeliharaan kesehatan masyarakat.

Hasil penelitian pendahuluan oleh Tim Peneliti, terbukti bahwa dekokta daun salam pada dosis $1,25 \mathrm{~g} / \mathrm{kg}$ BB mampu menurunkan kadar asam urat dalam darah mencit putih jantan secara efektif (Handadari, 2007) dan infusa daun Salam pada dosis $2,5 \mathrm{~g} / \mathrm{kg}$ BB mampu menurunkan kadar asam urat yang setara dengan allopurinol dosis $10 \mathrm{mg} / \mathrm{kg} \mathrm{BB}$ (Ariyanti, 2007). Ada pula penelitian yang menunjukkan bahwa pemberian ekstrak etanol herba meniran (Phyllanthus niruri L.) dapat menurunkan kadar asam urat ayam leghorn jantan yang dibuat hiperurisemia dengan diet purin tinggi (jus hati ayam) (Susanti, 2005).

Banyak penelitian menemukan meniran sebagai immunostimulator, yang sangat dibutuhkan oleh penderita penyakit-penyakit infeksi, juga berkhasiat sebagai antioksidan dan antineoplastik (antikanker). Selain itu juga berkhasiat sebagai imunoterapi atau terapi pendamping obat-obat kanker lainnya (Novalina, 2003). Berdasarkan pengujian praklinik sebelumnya secara in vivo pada mencit, tentang aktivitas antihiperurisemia dari beberapa tumbuhan obat asli Indonesia, 
diperoleh hasil bahwa kombinasi ekstrak Meniran-Tempuyung-Jinten Hitam merupakan salah satu kombinasi yang cukup poten dalam menurunkan kadar asam urat dalam darah mencit yang diinduksi dengan potasium oksonat (Muhtadi dkk, 2010). Oleh karena itu, ramuan dari ekstrak tanaman tersebut memiliki prospek untuk dikembangkan menjadi produk obat herbal atau fitofarmaka sebagai obat anti hiperurisemia. Untuk mendapatkan data yang lebih lengkap dan potensi pemanfaatannya sebagai obat antihiperurisemia, perlu dilakukan penelitian toksisitas untuk melengkapi data tingkat keamanan dalam penggunaannya.

Tulisan ini akan melaporkan hasil uji toksisitas akut untuk mengamati efek samping atau tingkat keamanan ekstrak dalam jangka pendek penggunaan. Uji toksisitas akut dilakukan dengan menggunakan parameter $\mathrm{LD}_{50}$ untuk mendapatkan dosis penggunaan yang aman, dilanjutkan dengan pemeriksaan histopatologi organ-organ tubuh yang vital yaitu hati, ginjal, lambung, usus, limfa, jantung dan paru-paru, untuk mengetahui derajat kerusakan yang mungkin ditimbulkan akibat pemakaian obat dalam jangka waktu tertentu.

\section{METODE PENELITIAN}

Alat : mikro pipet kepekaan $0,001 \mathrm{ml}$, timbangan digital kepekaan $0,1 \mathrm{~g}$, sonde lambung, kapas, tabung Erlenmeyer, seperangkat alat ekstraksi untuk penyediaan ekstrak bahan.

Bahan : Ekstrak methanol daun salam, tempuyung dan biji jinten hitam yang diperoleh dari hasil uji praklinik sebelumnya, tikus jantan dan betina galur Sprangue Dawley dengan berat badan $175 \pm 25 \mathrm{~g}$, makanan dan minuman tikus, larutan $\mathrm{NaCl}$ fisiologis,

\section{Uji Toksisitas Akut}

Uji toksisitas ini dilakukan terhadap tikus jantan dan betina galur Spring Dawle dengan berat badan $175 \pm 25 \mathrm{~g}$. Masing-masing kelompok terdiri atas 5 ekor. Setiap kelompok diberi perlakuan dengan pemberian sediaan uji pada dosis tunggal (single dose), dengan prosedur sebagai berikut:

1. Hewan uji dikelompokkan menjadi 5 kelompok dengan masing-masing kelompok terdiri dari 5 ekor tikus jantan dan 5 ekor tikus betina.

2. Ditimbang berat badan masing-masing hewan uji.

3. Ditentukan peringkat dosis sediaan uji, pada tahap awal mengacu dosis lazim dari uji toksisitas in vitro kemudian dilakukan uji pendahuluan untuk orientasi dosis dimana dosis maksimum yang masih dapat diberikan atau dosis yang telah menyebabkan sebagian (50\%) hewan uji mati ditetapkan sebagai dosis tertinggi kemudian dosis tersebut diturunkan berdasarkan faktor logaritmik atau rasio tertentu sedemikian hingga memberikan efek dari $0 \%$ sampai $100 \%$.

4. Ditentukan $\mathrm{LD}_{50}$, yaitu besar dosis yang menyebabkan kematian (dosis letal) $50 \%$ hewan coba, karena itu perlu diberikan dosis yang menyebabkan kematian > 50\% hewan coba, bila tidak dapat ditentukan $\mathrm{LD}_{50}$ maka diberikan dosis lebih tinggi sampai dosis tertinggi yaitu dosis maksimal yang secara teknis masih mungkin diberikan pada hewan coba.

5. Pemberian sediaan uji pada hewan coba dilakukan sesuai dengan cara penggunaannya yaitu secara peroral dosis tunggal.

6. Pengamatan hewan coba sudah dimulai sejak masa persiapan sebelum diberikan perlakuan (fase penyesuaian hewan coba terhadap situasi dan kondisis pelaksanaan eksperimen). Pengamatan dilakukan secara intensif, cermat, dengan frekuensi dan selama jangka waktu tertentu. Jangka waktu pengamatan yang lazim adalah 7-14 hari.

7. Kriteria pengamatan meliputi:

a. Gejala klinis (perilaku, gerakan, kepekaan terhadap rangsang, ukuran pupil, pernafasan, kelopak mata, bola mata, diare dan keadaan umum).

b. Perubahan berat badan.

c. Jumlah hewan coba yang mati pada masing-masing kelompok

d. Histologi organ hati, ginjal, lambung, jantung, paru-paru, usus dan limfa.

Masa pengamatan gejala klinis dilakukan selama 3 jam sejak perlakuan sediaan uji, sedang pengamatan jumlah hewan coba yang mati dilakukan sampai dengan 24 jam.

8. Hewan coba yang bertahan hidup sampai batas akhir masa pengamatan juga perlu dihistologi. Hewan coba yang menunjukkan gejala efek toksik namun tidak dikorbankan bermanfaat untuk diamati terjadi tidaknya pemulihan.

9. Hasil pengamatan dianalisis statistik. Dari jumlah hewan yang mati pada masingmasing kelompok, dihitung nilai $L_{50}$ menurut cara: Metode kertas grafik logaritma Farmakope Indonesia.

10. Perhitungan LD50 menurut Farmakope Indonesia: $m=a-b\left(\sum\right.$ pi-0,5) dengan syarat:

a. Menggunakan seri dosis dengan pengenceran kelipatan tetap

b. Jumlah hewan percobaan tiap kelompok harus sama

c. Dosis diatur sedimikian rupa sehingga memberikan efek dari 0\% sampai $100 \%$ dan perhitungan dibatasi pada kelompok percobaan yang memberi efek dari 0-100\%. 


\section{HASIL DAN PEMBAHASAN}

\section{Peringkat Dosis Ekstrak Uji}

Peringkat dosis uji toksisitas akut kombinasi ekstrak meniran, tempuyung dan jinten hitam dengan formulasi 1,5: $3: 1,5$ dalam penelitian ini dibagi menjadi 5 (lima) seri dosis untuk masing-masing kelompok terdiri dari 5 ekor tikus jantan dan 5 ekor tikus betina galur SD. Peringkat dosis tersebut adalah:
Dosis I : $100 \mathrm{mg} / \mathrm{KgBB}$
Dosis II : $300 \mathrm{mg} / \mathrm{KgBB}$
Dosis III $\quad: 900 \mathrm{mg} / \mathrm{KgBB}$
Dosis IV $\quad: 2,70 \mathrm{~g} / \mathrm{KgBB}$
Dosis V : 8,10 $\mathrm{g} / \mathrm{KgBB}$

\section{Pengamatan Kualitatif Gejala Klinis}

Pengamatan gejala klinik yang dilakukan meliputi: aktivitas gerak, kejang, reflek kornea, muntah, perilaku, dan reflek badan. Hasil pengamatan untuk tikus betina dan jantan terlihat pada tabel 1. Secara kualitatif tidak ada perubahan yang signifikan antara sebelum perlakuan dan 14 hari setelah perlakuan. Hal ini berarti bahwa pemberian kelima peringkat dosis kombinasi 3 ekstrak tidak menyebabkan timbulnya gejala-gejala toksik selama penelitian berlangsung.

Tabel 1- Hasil Pengamatan Gejala Klinik Tikus Betina dan Jantan Akibat Pemberian Sediaan Uji Selama 14 Hari

\begin{tabular}{|c|c|c|c|}
\hline $\begin{array}{l}\text { Kelompok } \\
\text { Perlakuan }\end{array}$ & $\begin{array}{l}\text { Dosis Sediaan } \\
\text { Uji (mg/kgBB) }\end{array}$ & $\begin{array}{c}\text { Jumlah Hewan } \\
\text { Uji }\end{array}$ & Gejala Toksik yang Timbul \\
\hline I & 100 & 10 & \multirow{5}{*}{$\begin{array}{l}\text { aktif } \\
\text { aktif, agresif terhadap peneliti } \\
\text { Aktif, agresif terhadap peneliti, ada beberapa bulunya } \\
\text { mudah rontok dan sedikit berdiri } \\
\text { bulu berdiri, perilaku semakin aktif, agresif terhadap } \\
\text { peneliti, vokalisasi, ada beberapa tikus bulunya } \\
\text { mudah rontok } \\
\text { bulu berdiri, ada beberapa tikus bulunya mudah } \\
\text { rontok, perilaku pasif bermalas-malasan ada juga } \\
\text { beberapa yang aktif dan feses agak lembek dan } \\
\text { sebagian ada yang mencret }\end{array}$} \\
\hline II & 300 & 10 & \\
\hline III & 900 & 10 & \\
\hline IV & 2700 & 10 & \\
\hline V & 8100 & 10 & \\
\hline
\end{tabular}

\section{Perkembangan Berat Badan Dan Jumlah Hewan Uji Mati}

Berdasarkan hasil pengamatan perkembangan berat badan dan jumlah hewan uji yang mati menunjukkan bahwa dengan pemberian ekstrak uji dosis tunggal secara peroral pada tikus sampai dengan dosis maksimal yang dapat diberikan secara teknis pada hewan uji yaitu $8100 \mathrm{mg} / \mathrm{kgBB}$ ternyata tidak menimbulkan kematian pada hewan uji dari seluruh kelompok, sehingga potensi ketoksikan akut ekstrak uji tidak dapat ditentukan. Oleh karena itu, untuk penentuan potensi ketoksikan akut dapat digunakan nilai $\mathrm{LD}_{50}$ semu, yaitu nilai dosis tertinggi yang secara teknis masih dapat diberikan pada hewan uji. Jadi nilai $L_{50}$ sediaan kombinasi ekstrak meniran, tempuyung dan jinten hitam secara oral dosis tunggal untuk tikus lebih besar dari $8100 \mathrm{mg} / \mathrm{kgBB}$. Hasil tersebut mempunyai makna toksikologi bahwa potensi ketoksikan akut ekstrak uji menurut kriteria Loomis (1978) termasuk dalam kategori praktis tidak toksik. Jumlah hewan uji yang mati padac pemberian ekstrak tabel 2 di bawah ini:

Tabel 2- Hasil pengamatan jumlah hewan uji yang mati setelah selama 14 hari setelah pemberian sediaan ekstrak uji secara oral

\begin{tabular}{cccccc}
\hline Kelompok & $\begin{array}{c}\text { Dosis Sediaan } \\
\text { Uji (mg/kgBB) }\end{array}$ & $\begin{array}{c}\text { Jumlah } \\
\text { Hewan Uji }\end{array}$ & $\begin{array}{c}\text { Jumlah Hewan } \\
\text { Uji yang Mati }\end{array}$ & Respon (\%) & LD $_{50}$ Semu \\
\hline I & 100 & 10 & 0 & 0 & $>$ dosis \\
II & 300 & 10 & 0 & 0 & tertinggi 8100 \\
III & 900 & 10 & 0 & 0 & $\mathrm{mg} / \mathrm{kgBB}$ \\
IV & 2700 & 10 & 0 & 0 & 0 \\
V & 8100 & 10 & 0 & & 0 \\
\hline
\end{tabular}

\section{Histopatologi Organ}

Hasil pengamatan secara makroskopik terhadap organ-organ vital diantaranya jantung, paru-paru, ginjal, hati, lambung, usus dan limfa tidak menunjukkan adanya perubahanperubahan yang menandakan terjadinya efek toksik terhadap organ. Hal ini dapat membuktikan bahwa kombinasi ekstrak meniran, tempuyung dan jinten hitam dengan dosis tertinggi secara teknis dapat diberikan secara oral yaitu $8100 \mathrm{mg} / \mathrm{kgBB}$ belum menimbulkan efek toksik terhadap tikus putih galur SD.

Hasil pengamatan mikroskopik juga menunjukkan sel-sel organ masih normal. (panah Gambar 1) 

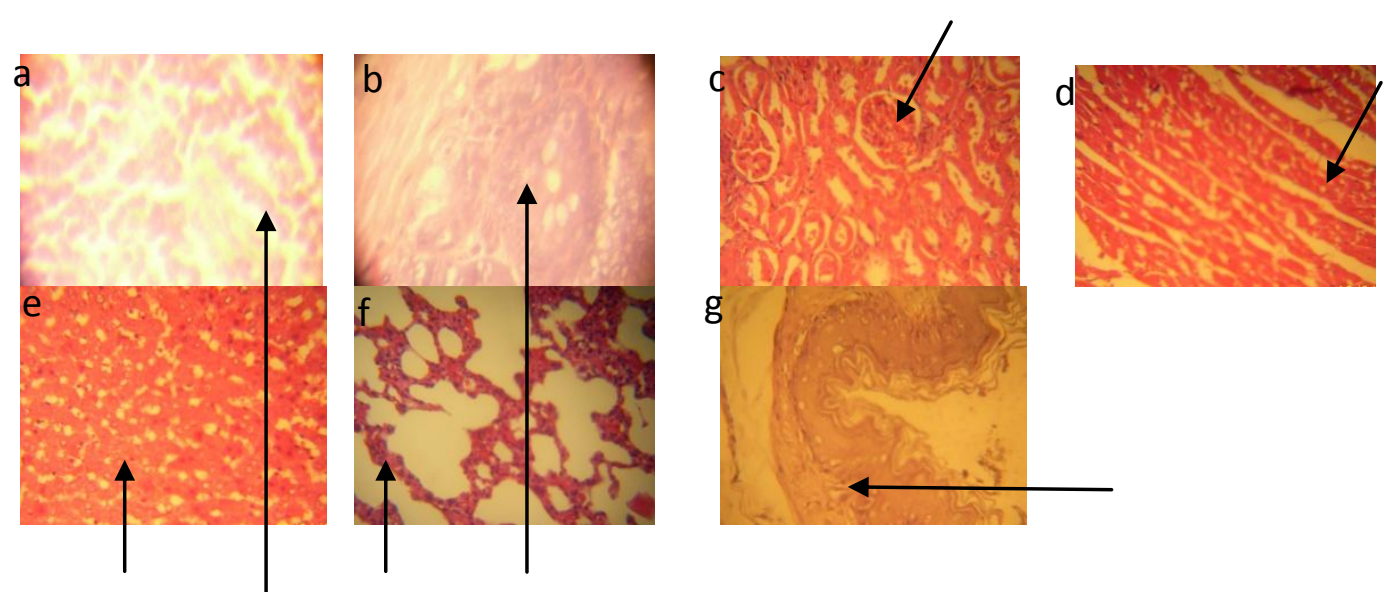

Gambar 1- Hasil histoldgi organ tikus setelah 14 hari pengamatan

Keterangan: a. Limfa, b. Usus, c. Ginjal, d. Jantung, e. Hati, f. Paru-paru dan g. Lambung

\section{KESIMPULAN}

Berdasarkan hasil analisis uji toksisitas akut terhadap kombinasi ekstrak air meniran, tempuyung dan jinten hitam dengan formula kombinasi 1,5:3:1,5 dapat dikatakan hampir tidak toksik untuk pemberian dosis tunggal dengan $\mathrm{LD}_{50}$ semu sebesar $8100 \mathrm{mg} / \mathrm{kgbb}$.

\section{DAFTAR PUSTAKA}

Ariyanti, R., 2007, Pengaruh Pemberian Infusa Daun Salam (Eugenia Polyantha Wight) Terhadap Penurunan Kadar Asam Urat Darah Mencit Putih Jantan Yang Diinduksi Dengan Potasium Oksonat, Skripsi, Fakultas Farmasi, Universitas Muhammadiyah Surakarta, Surakarta.

Dalimartha, S., 2000, Atlas Tumbuhan Obat Indonesia, Jilid I, Cetakan I, Trubus Agriwidya, Jakarta.

Handadari, H.R., 2007, Pengaruh Pemberian Decocta Daun Salam (Eugenia Polyantha Wight) Terhadap Penurunan Kadar Asam Urat Darah Pada Mencit Putih (Mus Muculus) Jantan Hiperurisemia, Skripsi, Fakultas Farmasi, Universitas Muhammadiyah Surakarta, Surakarta.

Jonosewojo, A., 2007, Implementasi Obat Alam Indonesia dalam Pelayanan Kesehatan Formal dan Alternatif, Makalah Seminar Nasional, Fak. Farmasi - UMS, 10 Maret 2007, 31-36.

Loomis,T., 1978. Essential of Toxicology, 3rd edition, Lea \& Febriger, Philadelphia.

Ma'at, S., 2003, Pengembangan Industrialisasi Fitofarmaka untuk Pelayanan Medis di Indonesia, Seminar Nasional, Fakultas Farmasi Universitas Muhammadiyah Surakarta.

Muhtadi, Sutrisna, Wahyuningtyas dan Suhendi, 2010, Pengembangan Agen Fitoterapi Asam Urat dari Beberapa Tumbuhan Obat Insonesia untuk Peningkatan Kapasitas Bahan Alam menjadi Produk Obat Herbal Terstandar (OHT), Penelitian Rapid yang belum dipublikasikan, UMS, Surakarta.

Novalina, 2003, Penggunaan tanaman obat sebagai upaya alternatif dalam terapi kanker. Pengantar ke Falsafah Sains, PPS Institut Pertanian Bogor, Bogor

Sudarsono, Gunawan, D., Wahyuono, S., Donatus, A. I., dan Purnomo., 2002, Tumbuhan Obat II Hasil Penelitian, Sifat-sifat dan Penggunaan, Pusat Studi Obat Tradisional, UGM, Yogyakarta.

Susanti, A., 2005, Pengaruh pemberian ekstrak maserasi etanol 70\% herba meniran (Phyllantus niruri L., ) terhadap kadar asam urat serum darah ayam leghorn jantan hiperurisemia, Skripsi, Surakarta

Wijayakusuma, H., 2002, Tumbuhan Berkhasiat Obat Indonesia Rempah, Rimpang dan Umbi. Prestasi Instan Indonesia, Jakarta. 